Available Online at https://journal.unismuh.ac.id/index.php/otoritas

Otoritas : Jurnal Ilmu Pemerintahan, 9 (1), April 2019, 73-88

\title{
Communication Deficit and Monetization of Political Contests at the Electoral Commission of Ghana
}

\author{
Shadrack Bentil1*), Edmund Poku Adu² \\ ${ }^{1}$ Department Institute for Intercultural and International Studies - InIIS, University of Bremen, \\ Mary-Somerville-Straße 7 D - 28359 Bremen, Germany. \\ Department of Public Administration and Health Management Sciences, University of Ghana, \\ P. O. Box LG 64, Legon-Accra, Ghana.
}

Received: 13 June 2018; Revised: 4 November 2018; Accepted: 25 Desember 2018

\begin{abstract}
The current state of the office of the Electoral Commission (EC) of Ghana can be couched as a bleeding pillar in Ghana's electoral democracy pending crisis. In spite of the numerous reform measures undertaken by the EC to improve the quality delivery of its constitutional mandate, communication deficit and the increasing monetization of parliamentary and presidential contestation poses a serious threat to broader participation and competition in Ghana's future electoral fortune. Thus, the objective of the paper was to interrogate the issues of communication inefficiencies and monetization of political contestations by the Electoral Commission of Ghana and proffer pragmatic solutions that can be taken into consideration in years ahead due to the past and recent experiences of neighbouring countries within the sub-region. The study employed the qualitative research methodology to elicit responses from 12 experts in the field of elections. Apart from the primary data generated from the field, secondary sources were consulted to situate the discussion in the existing debate in the literature. The findings of the study revealed that monetization of the political contest has negative implications for a competitive political contest--disqualification of citizens with capable minds from contesting in a multi-party democracy) whilst communication deficit was found to be deepening public distrust in the Electoral Commission of Ghana. The study, therefore, recommended among others the creation of a three-man office solely responsible for managing the commission's website and other electronic outlets, and the immediate activation and implementation of the provision in the 2020 Strategic Plan of the Electoral Commission which has remained dormant after 2016 elections.
\end{abstract}

Keywords: Electoral Commission; Public Trust; Communication Deficit; Monetization of Political Contest; Democratic Consolidation

How to Cite: Bentil, S., \& Adu, E. P. (2019). Communication Deficit and Monetization of Political Contests at the Electoral Commission of Ghana . Otoritas : Jurnal Ilmu Pemerintahan, 9(1), 73-88.

Permalink/DOI: https://doi.org/10.26618/ojip.v9i1.1344

${ }^{*}$ Corresponding Author.

E-Mail : sbentil@uni-bremen.de

Copyright (C) 2019, Otoritas : Jurnal Ilmu Pemerintahan, ISSN: 2088-3706 (Print), ISSN: 2502-9320 (Online) 
Available Online at https://journal.unismuh.ac.id/index.php/otoritas

Otoritas : Jurnal Ilmu Pemerintahan, 9 (1), April 2019, 74

\section{INTRODUCTION}

Globally, Election Management Body (EMBs) have proven to be the institutions on which electoral democracy and its consolidation hinge upon. The most valued quality of any EMB however, is its credibility, which can significantly increase election security, increased the legitimacy of electoral outcomes and reduce the risk of "political turmoil" (Cyllah, 2014). In principle, an EMB must adhere to a value of "openness and accountability, transparency and disclosure" just as required for political parties and contesting candidates (Goodwin-Gill, 1998). Deductively, the failure to observe these sacred tenets enjoining professionalism and independence of the EMBs can cripple democratic gains and destroy democratic norms giving way to democratic instability.

A work of Larry Diamond projects a global democratic recession, which implied a potential tip-over into a much worse scenario that could see the failure of democracy, not only in poor countries (Africa) but also in the big wigs such as Indonesia and Ukraine (Diamond, 2015). Additionally, he noted that the unprecedented cost of election campaigns, the heaving role of "non-transparent money" in politics, and increasing levels of voter apathy are other signs of democratic misfortunes (Diamond, 2015).

Relatedly Foa \& Mounk (2017) foresees a likelihood of democratic deconsolidation where growing democracies and highly democratic countries alike could give way to authoritarian regimes, though the level of consolidation will determine the pace of deconsolidation. They further observed, although democracy has come to be the solitary kind of government widely seen as legitimate, it has lost the confidence of many citizens who no longer consider that democracy can deliver on their most pressing demands and interests. That is, the enthusiastic assessment that this decline in trust simply repre- sents a momentary recession is no more than "a pleasing assumption, based in part on a reluctance to call into question the vaunted stability of affluent democracies." (Foa \& Mounk, 2017).

Additionally, a recent publication by Freedom House in early 2018 shows that there is a serious worldwide democratic crisis which cut across the basic principles of democracy. In the view of the president of Freedom House, Michael J. Abramowitz, the minimal ideals of democracy encompassing the assurance of "free and fair elections, the rights of minorities, freedom of the press, and the rule of law-are under siege around the world" (Freedom in the World Report, 2018). In the same vein, the Report saw that about 71 states experience net declines in political rights and civil liberties, whilst only 35 countries registered gains, of the 195 countries which were examined (Freedom in the World Report, 2018)

Significantly, electoral regimes are argued to be indispensable fundamentals in democratic regimes (Dahl, 2005; Merkel, 2004; Bogaards, 2009). Available literature also shows that 'Democracy' is incomplete without elections (Sandbrook 2000; Diamond, Linz \& Lipset, 1989; Sorensen, 1993) and thus, the office of the Electoral Commission as an independent and autonomous body to manage elections in Ghana is necessary for the survival of democracy. Hence, for Ghana's electoral democracy to deepen, the EC must be independent, impartial, professional and transparent such that 'the rules of the game' is applied fairly, particularly where there are very important positions in the country that must be contested for. Conversely, the failure of an EMB (EC) to organize free and fair elections may lead to the destruction of "public's faith" in the idea of multi-party democracy and the consolidation processes (Ayee, 1998) and a democratic reversal may be inevitable (Smith, 1960; Gyekye-Jandoh, 2013). 
In the scholarly works of Dahl, (2005), Merkel, (2004), \& Bogaards, (2009), electoral regimes are indispensable fundamentals in democratic regimes. But, can there be an electoral regime without existing Election Management Bodies (EMBs)? Arguably no, EMBs are central and important elements of electoral regimes even though they are not the only variables that matter in the conduct of elections in democratic regimes (Merkel 2004; Schmitter 1995). Furthermore, Frempong (2015) observed that "election administration is the thin line that separates the success and failure of transitional elections and that the character, competence, and composition of the electoral management body can determine whether an election becomes a source of peaceful change or cause of serious instability."

Significantly, democracy once on it wheels should progress rather than retrogress. Thus, situating earlier paragraphs in the context of Electoral Democratic Consolidation is not just desirable but necessary. This minimalist conception routed in the works of Adam Przeworski (1991) and Samuel Huntington (1991) places more emphasis on elections, an enterprise for which EMBs are the central figure. The adoption of this criterion for democratic consolidation is due to the fact that in most African countries (including Ghana) elections are very important to the peace, stability and to the continuation of democratic process. That is to say, most African countries have fragile institutions: it is either they have witnessed democratic reversal by overthrowing constitutionally elected governments or engaged in acts of secessionist movements or, the entrenchment of elected rulers to the seat of government with the intentions of manipulating political rules to consolidate their selfish parochial interest. By dint of this, countries seen to be practising democracy are mostly caught in the web of Electoralism with little or no attention to the issue of governance. Unarguably, the basic but crucial role of an Election Management Body is to lay a platform that allows for citizens to exercise their franchise within an institutionalized framework. These bodies become relevant when elections become a critical measure of democratic strides worldwide.

The literature shows that, most countries in the African Continent are caught within the sphere of electoralism (Botchway \& Kwarteng, 2018) such that democratic governing is perceived in limited scope to mean who occupies the seat of government or who is selected through electioneering structure within a space of time to allocate state resources and steer the processes of major decision in the country that applies to them. But the argument and emphasis of periodic or regular elections over the years have shifted to the question of quality and how free and fair, inclusive and legitimate electoral outcomes are likely to be (Malunga, 2016). Thus, inasmuch as Ghana conducts periodic elections, it is not enough grounds to write-off the likelihood of its outcome being illegitimate, and so constant reforms and reviews are needed to improve the efficiency and effectiveness of the electoral process.

Indeed, Civil Conflict that has electoral and political underpinnings are common in sub-Saharan Africa (Dupas \& Robinson, 2012; Blattman \& Miguel, 2010). Though, Ghana has not experienced these crises yet, the Kenyan and Ivorian experience (the controversial declaration of Mwai Kibaki and Laurent Gbagbo by the Electoral Commission of Kenya and Ivory Coast as the winners of keenly contested elections.) in 2007 and 2011 respectively, shows that Ghana is not immune to possible democratic reversal if the Ghanaian EC does not work assiduously in unfilled gaps (communication and Monetization) to avert any uneventful situations that could thwart Ghana's democratic feat. Es- 
pecially, when the evidence from neighbouring countries and the region by extension have revealed that failures electioneering processes decline public trust in the institutions responsible for overseeing elections (Election Management Body).

For this reason, irrespective of the enviable successes attained by Ghana electorally, the EC remains a sensitive and critical actor in the failure and/or success of electoral outcomes. Of course, the role of the Security agencies, Judicial Service, Media, CSOs and citizens are key but they do not declare elections. This explains why the paper put the Electoral Commission of Ghana in the centre of the discussion this paper in spite of the fact some African countries like Mali, Kenya, Tanzania, Burkina Faso, Burundi, among others have experienced shocks in their democratic foundations.

The coming into force of the 1992 Constitution of Ghana necessitated the provisions for the establishment of the office of the Electoral Commission (EC) by an Act of Parliament in 1993, as the mandated independent and autonomous body with the exclusive powers of overseeing elections in the Republic of Ghana. The mandate of the EC was to ensure that there is a fair play in the competition for people's votes. Perhaps, its inception signalled the hope that some reform measures would be undertaken to prevent the features of fraudulent elections under the office of INEC-Ghana from repeating itself, in the process of consolidating elections and democracy in Ghana.

Since its inception, the literature makes it clear that the EC has made considerable efforts to progressively accentuate the need for consolidating democracy by organizing periodic free and fair elections, carrying out public education, expanding voters register, creating new constituencies among others. For instance, the Electoral Commission (EC) has contributed to Ghana's impressive achievements in building the foundations for democratic governance which has resulted in six successive general elections. As noted by Gyimah-Boadi (2009), the objectivity, independence and administrative capability of the Ghanaian (EC) has gradually improved election by election, whilst levels of public interest in the general elections remain high.

Fobih (2011) espoused that the limitations to the drive of Ghana's democratic deepening hinge greatly on the institutional arrangements and the failure or the inability of emerging political parties or smaller political parties to wrestle for power boot-for-boot with the two dominant political parties to create a vibrant multiparty Democracy. From this argument, one would expect that aside the smaller political parties; effort could be made to a state fund for political parties to enable smaller parties to contest effectively, but that has not been the case. Fobih by way of recommendation argued for equal and level playing ground for political parties to allow for competitive contestations since that could gradually deepen electoral democracy (Fobih, 2011).

Notably, Amedeker (2013), observed that Ghana's democratic strides stem from the recognition and reverence for both political and civil right, and the commitment of Electoral Commission to constantly undertake credible steps towards the democratic consolidation business by instituting and laying out mechanisms to ensure political participation and reforms since its inception. Relatedly, Okra (2015) in his published thesis confirmed the works of (The World Governance Index, 2014 and Gyimah-Boadi, 2009) that EC has contributed positively to ensuring free and fair elections in Ghana. However, sustaining this feat requires putting in place the right communication mechanism to relay accurate and timely information to the political stakeholders and the citizens who are a major stake- 
holder in democratic deepening and sustenance. It is within this scope and light that the paper focuses on communication deficit that characterizes the office of the Electoral Commission.

A conference paper of Gyampo (2018) titled "Managing the Possibility of Election Overload In Ghana, 2018 -2021" focussed on the likely challenge overloads on Electoral Commission of Ghana ahead of several elections that are outstanding between the period of 2018 and 2021. Concluding that the EC is overburden with so much responsibility and thus the president's directive to conduct elections for Metropolitan, Municipal and District Chief Executives (MMDCEs) has greater potentials of deepening the "unending electoral cycle" of Ghana (Gyampo, 2018) which is likely to reduce the quality of elections in the country.

Even though literature on the Electoral Commission of Ghana abound ranging from the political conflict, democratic consolidation, electoral reforms, voter educations, political parties and internal conflicts, democratic governance prospects and challenges, to Political Vigilantism, little attention have been given to the space of monetization of political contest (the only work that sought to extensively explore this aspect is the 2018 February report by the Westminster Foundation in conjunction with the Center for Democratic Development (CDD)-the Cost of Politics in Ghana) and communication deficit which could be a recipe for democratic reversal, if uncheck. For instance, the Afrobarometer 2016 report under the caption "Election quality, public trust are central issues for Africa's upcoming contests" revealed a very minimal trust in the Election Management Body in their respective countries. According to Penar, Aiko, Bentley \& Han (2016), of the 36 countries which were survey, an average of $50 \%$ was seen to have trust in the Election Management Body of their respective countries: $25 \%$ said "A lot", an- other 25\% said "Somewhat", 23\% said "A little", a significant $22 \%$ said "Not at all" whilst 6\% said "Don't Know". Interestingly and unfortunately, Ghana the hailed and admired West African country so far as electoral democracy is concerned recorded a lower trust level of $37 \%$ in the Electoral Commission (Penar, Aiko, Bentley \& Han, 2016).

Obviously, considering the state of disbelief in the office of the Electoral Commission, one would expect effective communication from the EC to offset and dispel misconceptions within the political environment. Failure to do so can lead to undesirable outcomes that can impede and subsequently erode Ghana's efforts towards the consolidation of electoral democracy. It is for this reason that the choice of country and topic is justified. This notwithstanding is important to point out that no institution is perfect and would, therefore, need "constant reengineering" to make function at the most desirable level (Gyampo \& Asare, 2015). Therefore, the paper aims at examining the current state of the Electoral Commission of Ghana, primarily focusing on EC's communication deficits; monetization of parliamentary and presidential contests (MPPCs) and likely implications for Ghana's democratic future.

\section{RESEARCH METHODS}

The study was purely qualitative and merited a response from 12 experts, selected through purposive sampling due to the sensitive nature of the paper. Of the 12 respondents, 3 were highly-rated electoral officials, 4 representatives of the four dominant political parties in Ghana (1 each), 3 were representatives from three Civil Society Organizations, and 2 were Political Scientists. Notably, Creswell (2013) explained that the core of qualitative study lies in its analytical assessment of phenomena to enable the researcher to create an all-inclusive and a vivid picture of that phenomenon such 
that the processes and outcomes provide deeper insight into that phenomena and how it reflects the "outside world". In this vein, a qualitative approach was more suited for this study since it allowed the researcher more room to operate. Further, it helped the researcher to distil objectivity from subjectivity through logical inferences rather than to follow narrow measurements and rigid impositions of quantitative methods (Engel \& Schutt, 2009). Moreover, data derived from the use of the qualitative approach gave life to the research question and objectives of the study.

\section{RESULTS AND DISCUSSION}

\section{The Electoral Commission and Commu- nication deficit}

For the first time in the history of Ghana, the Electoral Commission instituted a strategic plan to become a "World Class, Trusted and Independent Electoral Commission" (Electoral Commission Ghana Strategic Plan 2016 - 2020) within the period of 2016 and 2020. This was launched in the heat of several allegations surrounding the appointment of its chairperson, Mrs Charlotte Osei. Indeed, a clearly defined goal is ideal since the various variables and element could join together to reach a destination of excellence. The strategic plan, therefore, aimed to deliver the Commission's mandate, equipping the staff, effective utilization of the available resources the Commission have, the various processes, especially, technology and finally the brand of the Commission. This section, therefore, assesses the state of the EC against the five-year Strategic Plan after seventeen (17) months of launching and implementation. Though this exercise may be considered premature, it is a prudent endeavour to track the progress or dormancy of the strategic plan to enable the Commission to up their game in working fervently towards the achievement of their target.
No empire is built in a day and so for the commission to achieve its target, 17 months is fair to assess the journey so far.

As part of the strategic plan, effective communication was highlighted as a very important component to address rumours and conjectures which more often than not replaces fact. A journey in a milestone is often said to start with a step, but from all indications, nothing impressive can be said about the Commission as far as communication both internally and externally are concerned. The IDEG official revealed that the EC has not done enough to show that the communications aspect of the World Class Strategic Plan will be achieved in the next 26 or 27 months ahead of 2020 elections in spite of the fact that the head of communications was changed prior to 2016 for reasons of not being proactive and ineffective communication.

On the contrary, the change did not bring a drastic shift to an improved communication since levels of inconsistencies in the communications of the EC persisted. This came to a head in during the 2016 general election press briefing; where the Head of the EC Communications, Mr Eric Dzakpasu clarified the silence of the EC in a press conference, stating that electoral results that made it way to the National Coalition Center has several allegations of over voting across the country and the issues are been investigated-this inaccurate information heightened the tension in the country particularly when no such allegations were made at the polling stations. The issue was compounded by the Commission's Chair Person, Mrs Charlotte Osei that an Electronic Results Transmission System (ERTS) for the 2016 elections has been compromised. The information came as surprised since the EC did not communicate to stakeholders that there were reengagement with some IT firms to perform this task. The data revealed that the EC was not satisfied with presentations of 
all the IT firms that responded to the bid of handing the Electronic Results Transmission System (ERTS) proposed by the Electoral Reform Committee. Thus, for the EC to take a unilateral decision was surprising and unethical.

The largest platform the Commission engages with external actors or stakeholders in through the Interparty Advisory Committee (IPAC). However, for effective dissemination of information commission has instituted the Regional Interparty Advisory Committee (RIPAC) and the Interparty Advisory Committee (DIPAC). The RIPAC and the DIPAC especially have been dormant and ineffective due to the lack of offices in some districts or malfunctioning district offices of the Electoral Commission across the country (Ghana).

The IDEG and CODEO officials including the Political Scientist who were interviewed expressed that, the decisions at the national level (IPAC) does not trickle down to the RIPAC and DIPAC because most of the parties are not so organized into these sections to constitute a formidable front for the dissemination of information. Additionally, it was revealed that the meetings are not done properly due to the lack of district offices of political parties across the country. Thus, one would expect that the EC would have started working in this regard but no significant efforts have been made to this effect.

To illustrate, for instance, at least from January to May 2017, there had not been any proper IPAC meetings, the EC had not published the official election results for 2016 and there no communications coming from the Commission, a development which was in sharp contrast to the traditions of the EC before the conduct of the 2016 elections. Moreover, the absence of communication and dormancy in dealing with the stakeholders leads to suspicion which is not good for the Commission's effort to instil trust and transparency in the discharge of its mandate the people.

The PPP official, expressed that the failure of the commission to engage political parties in IPAC meeting for close to five months after elections very strange because before and during the 2016 elections, the EC Chair was very vociferous in responding to claims and allegations but the EC seems to have suddenly gone to sleep. This view questions the integrity of the EC Chair which supports the dwindling stakeholder trust in the Commission and how it operates. The finding confirms Penar, Aiko, Bentley \& Han (2016) in the analysis of the worsening decline in EMB trust in West Africa.

Similarly, the data revealed that there is no formal way in which the Civil Society Organizations (CSOs) are engaged by the EC like the way the EC engages the political parties (the EC engages political parties in a monthly IPAC meetings and also in the fortnights before elections dates, however, no such formal platform exist for election-related CSOs in Ghana). But elections are not organized solely for political but most importantly for the people.

The Election-related CSOs who volunteered their responses argued that the engagement of CSOs on a formal platform can enrich debates and decisions of the EC since they have representatives and officials in the across the grassroots in the country who constantly engage the peoples and the information they present are more likely to be credible and authentic.

According to the IDEG official, it is expected that the EC interact with the CSOs who represent the people who vote on a regular basis, but this expectation seems to have either eluded the EC or is on the blind spot of the Commission, and as a result, no effort has been made to periodically interact with CSOs who will, in turn, disseminate the information to the general populace, even if the interactions of the Commission with the CSOs may not be as regular that of the political parties. 
That is to say, there should be a balance interaction between the EC and the Political Parties on one hand and the interactions on the EC with the people represented by the CSOs on the other so that the CSOs would not be called upon only when their services become relevant to the Commission. Though the Political Scientists considered this move as brilliant, they were concerned were concerned about space, cost and wondering what difference joining the IPAC meetings on a single platform will make. One of the Political Scientists argued that the EC sometimes have discretionary powers (unilateral decision) in spite of the proceeding at the IPAC meeting and so if civil societies groups have a concern, they can equally put it in writing as has been the norm but not necessarily being present at the meetings.

Of course, cutting cost is equally important as effective communication. From a neutral standpoint, the political parties are salespersons and will most often than not sell what they want citizens to hear. However, the EC as the referee has most often delayed communicating to the citizens directly on fallouts of IPAC meetings. The Media and CSOs on the hand have the fastest means of disseminating information and thus being a part of IPAC meetings to pick 'first-hand information' and disseminate them accurately is far better than waiting on press release from the Commission when the inaccurate information has already been spread by political parties to their supporters and citizens have formed their opinions. The call could be a crucial way of improving communication and refining the dissemination of information as well as reducing stakeholder's distrust.

Additionally, the EC sought to improve communications through the use of technology. However, the necessary information that ought to be at the Commission's Websites are not readily available. The Website is noted for constant shut- down and this gives room for the circulation of information that is not credible. For more than six months after the EC had declared the 2016 election results, the official election result was not available on the EC's Website. Here again, the EC seems to be failing to make significant progress that shows a path to the achievement of the Strategic Plan by 2020. The Former EC Chairman admitted the challenge and explained that communication is a serious challenge the commission has been working from time to time to improve but the challenge is most often the delays and timely release of the information. The fear of figures generating contradictions within the polarized political sphere calls for double-check and data verification data, which unfortunately delays the process.

The deductions from this argument point to the fact that the EC has not devised effective means of generating and aggregating data. This slows communication leaving room for disseminating false interpretations. Moreover, not everyone could drive to the headquarters of the EC to access authentic information in the name of 'what the people will say.' The citizens deserve quick access to accurate information in order to build total trust in the Commission, the reverse is always detrimental to the trust and integrity the people accord to the Electoral Commission.

It is worth noting that before the appointments of new EC Chairpersons, the Commission's head and two deputies were divided against themselves and for that matter, no effective communication could exist. The evidence points to fact that there was a clash of personality and this created friction between the three (the Chairperson and the two deputies) in terms of building consensus on critical electoral issues including procurement. This was because the two deputies were familiar with the organizational culture whilst the then Chair, Mrs Charlotte Osei 
was more or less a novice to the electoral game (elections). Unfortunately, the communication deficit between them is believed to have deepened the rivalry between them.

Thus, the new Commissioners would have to develop innovative ways of enforcing the communication plans and strategies outlined in the 2020 Strategic Plan or devise an effective means of interacting among themselves as well as interacting with political parties, CSO, the Media and the Citizens at large to restore the image of the EC which has being smeared in fraudulent transactions and misappropriations-partly as a result of ineffective communication among the immediate past heads of the Electoral Commission of Ghana. The move will further improve communication, enhance credibility and ensure sanctity and accuracy of the disseminated information between now and the next elections in the year 2020.

The failure of the EC to Gazette Election 2016 Results new developments

The Electoral Commission against its normal tradition did not gazette the 2016 election results for more than 6 months from the day declaration of election results. The situation was alarming because anybody could have challenged the election result. This notwithstanding, polling station results were not published until after 6 months. The critical question here is, how were the 2016 elections declared and with what data was the final computations done? The Commission is indeed in crises and a lot has to be done to salvage it from crumbling. It is daunting for an EMB like the Ghanaian EC to conduct elections and publish national and regional results without polling station results.

The failure of the EC to gazette leads to another question as to what mechanism the EC employed to gather and aggregate polling station, constituency, and regional election results to arrive at the final results that declared President Akufo
Addo as the winner of the 2016 election contest. Another question that has still not been answered is to what extent did the compromised electronic transmission noted by the Commission's Chair during a press briefing in 2016 affected the results that were transmitted through that channel.

Again, from the responses of the CSOs, Political Scientists, One of former deputy EC and the political parties' interview with the exception of the NDC official, there were several infractions in the 2016 elections, but the landslide victory for the New Patriotic Party (NPP) created a low tempo in the political environment. To illustrate, the PPP official expressed disappointment in the electoral; the electoral system is such that some persons were able to trigger electoral thievery which has been deepening and it came to its peak during the 2012 and 2016 could have been worse since the election rigging has progressed. This observation can sink into the deterioration of stakeholder trust in the Electoral system. This tends to confirm the observation of Penar, Aiko, Bentley \& Han (2016) on the decline of trust in EMBs in Africa.

However, the perspective of the former EC Chair disagrees with the opinion of the PPP official and other political parties who were not explicit with expressions on these grounds, first, Election is a big deal with multifaceted happening and this necessitated the introduction of the "counting at the polling stations" to resolve problems with the results at the polling station. The system makes it easy to trace particular mistakes by following the records at the polling station and this system was being built systematically over the and now it has really come to stay.

Second, unless there is an obvious mistake with the results, all other unclear mistakes or disputes over results have to be proven with empirical evidence and facts either with the commission or in 
court because the commission is the least party to rig elections in Ghana. Most importantly, he noted that "elections are won or lost at the polling station" is not new to the political parties since it is mostly stressed- the power is in the hands of the so when the polling station agents: what they endorse is the real fact and cannot be disputed.

The above, notwithstanding, the Commission currently has a new phase following the dismissal of Mrs Charlotte Osei and her two deputies as recommended by the chief justice's committee after the completion of an investigation into a fraudulent and corruption allegation brought against the EC chair by the members of the commission and the two deputy Chairpersons of the Electoral Commission were found to be credible and factual. The implication of this development has greater chances of deteriorating public trust further. The point is that, since the inception of the Commission, it is the first time the Electoral Commission's Chair and her deputies have been sacked. The question now is, will a change in personnel positively salvage the declining faith in the office or a new era for more disaster? Interestingly, the newly appointed leaders of the commission have signed two years bond and forge ahead towards the 2020 general elections of Ghana whilst a referendum lingers on the neck of the in December 2018.

Aside this, about two (2) of the members of the EC are due for retirement before 2020, what this means is that the NPP government again will have to appoint three people to fill up the space created by the compulsory retirement of the three members of the commission. The most obvious will be that the NPP would have appointed six (6) members out of seven-member Commission (One Commission chair, her two deputies and three shall be the replacement to the three retirees). What will the posturing and level of trust of the opposition political parties and their fanatic supporters on the reconstituted Electoral Commission in a highly politicized country like Ghana ahead of the 2020 general elections? The challenge, therefore, remains with how this new commissioner within limited time will synergize the World Class Strategic Plan, which is the focus and target for the outgone administration with their new strategy ahead of the 2020 general elections. Given that, the new Commission will stick to the World Class Strategic plan, implementation will be difficult since a lot of time will need to learn and familiarize themselves with the stipulated procedures that have been instituted by the current Electoral Commission.

A deduction from the legitimate questions and the analysis above, danger looms ahead of Ghana's election 2020 if the right measures are not taken to arrest any eventualities. The Institution of the Electoral Commission is very critical to the stability of Ghana and must not be politicized. This is because a politicized EC is a recipe for conflict and mistrust and when mistrust compounds in the midst of a highly politicized country, tensions are heightened and the legitimacy and the validity of an electoral outcome will be challenged-The outcome of the Chief Justice's report concerning the commission certainly will have an impact on how the political environment of election 2020 will look. The state of the office of the Electoral Commission of Ghana, therefore, is a frog in gradually boiling water: Its outcome will be undesirable if the necessary steps are not taken to salvage the situation.

\section{The Electoral Commission of Ghana and Monetization of Parliamentary and Presidential Contestations}

In Africa and beyond, money politics is not a recent phenomenon. This occurrence is most often than not associated with vote buying and electoral fraud. It is a well-known fact that democracy is an 
expensive system to operate in any country in terms of time and resources. But, should the expensive nature of the system (democracy) set money as the locus and centre of electoral competitions, where potential citizen are excluded from political contestations? Undoubtedly, money is essential for the sustenance of the electoral system but in instances where it is given the chance to occupy so much space the Ghanaian electoral politics, democracy becomes moneycracy-a development that can cripple Ghana's electoral successes and dent the credibility the Electoral Commission has built over the years. The answer to the earlier question is ideally a simple No if electoral democracy is indeed valued by Ghanaians. Moreover, monetization breeds presidential and parliamentary corruption. Having used huge sums of money to get elected into public offices, the next move is to amass wealth to pay either their debtors, financiers, and also settle individuals who may have contributed to their success. This fit into Stephan Limburg's "it is our time to chop" (Lindberg, 2003).

\section{MPPCs and Competitive Elections}

Monetization of Parliamentary and Presidential Contestations (MPPCs) employed by the researcher should be conceived and understood as a situation where an Elections Management Body (EMB) to attach high financial commitments to the filing fees for candidates (Political Parties or individuals) who are seeking to contest for presidential or parliamentary elections within a stipulated period of time-the failure to meet this requirement within the allotted time tantamount to disqualification of candidates involved. This situation is also described by William (1997:169) as "monetization of the electoral process". But for the purpose of a defined scope, I use the MPPCs to paint a clear picture of the Ghanaian experience.

Though democracy is expensive to practice, democracy is not a system for the rich. In this regard, poor persons with capable minds should be able to participate in the democratic processexcessive monetization kills the potentials of affable leaders who are financially incapacitated. For example, few weeks to the 2016 election, the EC increased the filing fees from GHS1, 000 to GHS10, 000 for parliamentary candidates and from GHS5, 000 to GHS50, 000 for presidential candidates. The capricious decision by the Commission to increase the filing fee can inhibit the poor but capable of contesting parliamentary or presidential elections.

Monetization, therefore, kills Political Mobilizations. This is expressed in the concerns of the smaller political parties since their number does favour a sudden hike in filing fees to file their nominations. The PNC official was very passionate and vociferous on this, he argued that the EC GHC hike in parliamentary filing fees from GHC 1,000 to GHC 10, 000 political parties both dominant and smaller parties, within a short period to elections was insensitive to the smaller political parties and an indirect way of reducing competition. The justification stems from the fact that since GHC 10, 000 could secure 4 motorbikes to facilitate the campaign of the smaller parties but the EC requires it as a deposit. For example, the Northern part of Ghana have villages that are wide apart and so a motorbike is crucial to carry out village-to-village and house-to-house campaigns, one of the best ways to garner votes. Such decision by the EC is no less reducing the campaign coverage of smaller political parties since they are financially stretched, unlike the major political parties. Moreover, it has been argued that the government is a serious business and thus the players must be well to do or have the means to govern so as to reduce political kleptocracy. However, this notion is misleading as it rather hampers competition and gives too much attention to money rule. 
Another negative impact of a reduction in the competition which is key to democracy the monetization had on the mobilization is that the announcement of the increment came late after the political parties and independent candidates have already budgeted for the filing fees already. The sudden increase necessitated dropping some the candidates for lack of funds: who do you drop and will must the party support? It brings division into the parties; this has been one of the main reasons why some political parties are unable to contest in some constituencies during general elections (especially, the minor political parties). Though no independent candidate dropped out of the 2016 race, an Independent candidate who is unable to meet the financial requirement in future would have to step after a lot of resources has been utilized towards their political agenda or ambitions. This to a very large extent reduces competition in the contest for people's vote to manage the affair of the state.

In spite of the fact that the monetization focuses on the EC, it was revealed that monetization and vote buying is increasingly becoming a part of the Ghanaian elections from the grassroots to the national level. The EC officials and the CSOs argued that the monetization at the political party's level is more worrisome. The concerns raised confirms media reportage on some key political actors who perceive the eminence of money politics destroying the quality of elections and political contests. For example, the revelation confirms the observation made by the former Speaker of Parliament, Edward Doe Adjaho, who bemoan describing the excessive monetization as contributing to incessant corruption as well reduction in the quality of members of the house and the level of arguments and this could have negative implication for Parliamentary business (Gadugah, 2015).

Relatedly, the data revealed that politicians resort to monetarist and material inducement tactics instead of ideas, policies and pragmatics agenda that could transform citizen's lives in order to bribe their way through a political contest to emerge-money wins power. This is confirmed by a fairly recent publication by Westminster Foundation in conjunction with the Center for Democratic Development (CDD) in February 2018 (Debrah, et al., 2018). According to Dr Kojo Asante a senior research fellow at the CDD, the phenomena has been left unattended to, and for the matter, the data which monetization is deteriorating Ghanaian Politics. This he opined, is a recipe for breeding 'godfathers' who will "directly or indirectly govern the country because they can afford to induce voters or sponsor other politicians to gain power with money".

Significantly, the monetization of the political contest by the EC according to the CSOs, Political Scientist, PNC and NDC officials could in the future make democracy as an auction where the highest bidder gains access to political contest but those with laudable ideas and experience may be side-lined because of financial inhibitions. For instance, democratic auctioning could give room to "money launderers", "drug barons" and even "terrorist groups" to sponsor individuals to hijack democracy due to the weighty money and resources at their disposal to cross the finish line. Though this observation is seemingly pessimistic, monetization of political contestations if unmanaged properly will further give tickets to people with radical ideas to parliament or the executive arm of government, the result is the laws that are made will be radical, they people may rebel and the country will be destabilized.

Lastly, research literature leads to the conclusion that "moneycracy" is sinking very deep into the Ghanaian political contests. The research findings of the Westminster Foundation in conjunction with the Center for Democratic Development (CDD) (also cited in Suhuyini, 2018.) 
shows that "it will cost a member of parliament USD $\$ 86,000$ to secure a party's primary nomination to compete in parliamentary elections in the country". This notwithstanding, the findings also advanced that, the cost of running for a public office (political office) in Ghana shot up to about $60 \%$ in the last four years $(2012$ 2016). There is, therefore, the need to device a proactive mechanism to address this political menace from eating into every facet of political life-especially when the evidence points to two critical institutions (political actors) namely the political parties and the Electoral Commission of the electoral commission of Ghana.

\section{CONCLUSION}

The Ghanaian Electoral Commission is one of the best if not the best in SubSaharan Africa. The evidence lies in the improved transparency and some level of credibility the constant and progressive electoral reforms that have been instituted by the Commission in the past 24 years. However, the fraud allegation against the Electoral Commission which was confirmed by the investigation of the Chief Justices Committee is a dent on the office of the EC and a threat to their credibility, though new officers are in the present in the driving seat of the commission. Indeed ineffective communication was found to be a major challenge the EC faces, especially in the management of the Electoral Commission's website. Though the EC tries to put basic information online, it is sometimes difficult to access information because of temporal shut down of the site. The study revealed the lack of coordination in the information put out by the Commission through their communicators and the EC Chairperson and this creates suspicions and reduction of people's trust in the system. More so monetization of parliamentary and presidential contestations by both the Electoral Commission and the Political Parties was found to be a likely avenue for demo- cratic auctioning where the highest bidder wins. The greater implication, therefore, lies in the level of democratic participation (broader participation) and competition which is a prominent tenet in democratic governance.

Ghana is deemed democratically consolidation by Samuel Huntington's conceptualization through the "Two Turnover Test" theory. Though Ghana's election over the years has been generally peaceful, less violence, and relatively free and fair though the last two elections (2012 and 2016) recorded some infractions which call for more work. Critical among these are the excessive monetization, ineffective communication and the dwindling public trust in the role of the EC. These challenges if unaddressed could hamper the furtherance of Ghana's democracy in years to come. Hence, the paper recommends the following for consideration, first, the EC should employ two or three IT specialists solely responsible for the management of the EC's website to allow free flow of information. In the same vein, the EC needs to introduce an electronic transmission of electoral results which is faster and more efficient than the manual process. This will gradually eliminate the trending declaration of results by political parties before the certified results from the EC. Secondly, IPAC should be expanded to include civil society organizations and the media since there is no compact platform for the EC to interact with the media and the CSOs that are related to the work of the EC. This will ensure that election-related CSOs are a preview of the necessary information to avoid dissemination of inaccurate facts. Aside these, the EC must reenergize Regional Interparty Advisory Committee (RIPAC) and District Interparty Advisory Committee (DIPAC) to further engage the political parties and CSOs and the media at both regional and district levels to build a formidable front for the dissemination of information at the grassroots. 
Thirdly, there is the need for a committee to be set up to consider how a constitutional amendment request could be made to amend Article 71 (2) of the 1992 Constitution of the Republic of Ghana, which states that "the President shall, acting on the advice of the Council of State, appoint the Chairman, Deputy Chairmen, and other members of the Electoral Commission." This to a large extent will reduce if not to eradicate the tension and the level of executive interference that comes with the appointments to the Seven-member Commission. Finally, there is the need for permanent staff screening and effective mechanism for recruiting new permanent staff at the EC to reduce the rate of partisan associations which tends to influence the decision of individuals to put their party interest at the apex against the national interest. To wit, every staff of the commission must be screened by the Bureau tor National Investigations (BNI) whilst extending this screening to new staffs of the Commission with a major focus on backgrounds checks.

\section{ACKNOWLEDGEMENT}

The authors gratefully acknowledge research support from our supervisors and the respondents who volunteered their time and energy to provide the primary data for this paper.

\section{REFERENCES}

Amedeker A. M. (2013) An assessment of Ghana's democratic consolidation since 1992 and the implications for international relations. Accra, Ghana.

Atieno, 0. P. (2009). An Analysis of the Strengths and Limitation of Qualitative and Quantitative Research Paradigms. Problems of Education in the 21st century, 13, 13-18.

Ayee, J. R. A. (1998) "The 1996 General Elections: An Overview" in Ayee ed. The 1996 General Elections and Democratic Consolidation in Ghana. Accra: Gold Type Ltd, 3552

Blattman, C, \& Miguel. E. (2010). "Civil War." Journal of Economic Literature, 48 (1): 3-57. DOI: 10.1257/ jel.48.1.3

Bogaards, M. (2009), How to Classify Hybrid Regimes? Defective Democracy and Electoral Authoritarianism, in Democratization, 16, 2, 399-423.

Botchway, T. P., \& Kwarteng, A. H. (2018). Electoral Reforms and Democratic Consolidation in Ghana: An Analysis of the Role of the Electoral Commission in the Fourth Republic (1992-2016). Asian Research Journal of Arts \& Social Sciences, 5(3): 1-12; ISSN: 24564761

Creswell, J. W. (2013). Qualitative inquiry \& research design: Choosing among five approaches (3rd ed.). Thousand Oaks, CA: Sage Publications, Inc

Cyllah, A. (2014). EMBs and Electoral. In A. Cyllah, \& A. Cyllah (Ed.), Elections Worth Dying For? A Selection of Case Studies from Africa. International Foundation for Electoral Systems, 1-199

Dahl, R. A. (2005), What Political Institutions Does Large Scale Democracy Require? In: Political Science Quarterly, 120, 2, 187-197.

Debrah, E., Attoh, D. A., Norviewu, N., Adu, K., Amanfo-Tetteh, R. O., Asiamah, G., Tetteh, M. (2018). The Cost of Politics in Ghana. West Mister for Democracy (WMD) and Center for Democratic Development (CDD, Ghana). Retrieved from http:// www.wfd.org/wp-content/ uploads/2018/04/ 
Available Online at https://journal.unismuh.ac.id/index.php/otoritas

Otoritas : Jurnal Ilmu Pemerintahan, 9 (1), April 2019, 87

Cost_Of_Politics_Ghana.pdf

Diamond, L. (2015). Facing up to the democratic recession. Journal of Democracy, 26(1), 141-155.

Diamond, L., Linz, J. J., \& Lipset, S. M. (1989). Democracy in Developing Countries. Boulder: Lynne Rienner.

Dupas, P. \& Robinson, J. ～(2012, November). The (hidden) costs of political instability: Evidence from Kenya's 2007 election crisis. Journal of Development Economics. 99 (2), 314-329.

Engel, R. J., and Schutt, R. K (2009). The Practice of Research in Social Work (2nd ed.) Thousand Oaks, CA: SAGE, 1-583.

Fobih N. (2011) Challenges to party development and democratic consolidation: Perspectives on reforming Ghana's institutional framework. Journal of Asian and African Studies. 46(6):578-592.

Freedom In the World Report (2018) Democracy in Crisis. Freedom House. Retrieved from: https:// freedomhouse.org/report/ freedom-wo rld/freedom-world2018

Frempong, A. K. D (2015). Elections in Ghana (1951-2012), Accra: Life@60 Publishers.

Gadugah, N. (2015, February 25). Monetization of Ghana's politics is the cause of corruption-Adjaho. Accra, Ghana. Retrieved from http:// www.Myjoyonline.com/ monetizationofGhana'spolitics-isthe-cause-of-corruption-Adjaho

Goodwin-Gill, G. S. (1998). "Codes of Conduct for Elections". Geneva: InterParliamentary Union.

Griffin, C. (N.D). The Advantages and Limitations of Qualitative Research in
Psychology and Education. pp 315.

Gyampo, R.E.V. \& Asare, E.B. (2015). The church and Ghana's drive towards Democratic Consolidation and Maturity. Journal of Church and State, doi:10.1093/CSV095. Oxford University Press. 1-22

Gyekye-Jandoh, M. A. (2013). Electoral Reform and Gradual Democratization in Africa: The Case of Ghana. African Journal of Social Sciences, 3, 74-92.

Gyimah-Boadi, E. (2009, April). Another step forward for Ghana. Journal of Democracy, 20(2), 138-152.

Huntington, S. P. (1991). The Third Wave: Democratization in the late twentieth century. Norman: University of Oklahoma Press.

Lindberg, S. I. (2003). 'It's Our Time to" Chop"': Do Elections in Africa Feed Neo-Patrimonialism rather than Counter-Act It?. Democratization, 10(2), 121-140.

Malunga, S. (2016) A review by Open Society Initiative for Southern Africa and ECF-SADC. Retrieved from: http://www.africanminds.org.za and www.osisa.org

Merkel, W. (2004). Embedded and Defective Democracies, in Democratization, 11, 5, 33-58.

Penar, P., Aiko, R., Bentley, T., \& Han, K. (2016, September) 'Election quality, public trust are central issues for Africa's upcoming contests'. Afrobarometer Policy Paper No. 35.

Sandbrook, R. (2000). Closing the Circle: Democratization and Development in Africa. Toronto: Zed Books.

Schmitter P. C., (1995) Speculations about the Prospective Demise of Author- 
Available Online at https://journal.unismuh.ac.id/index.php/otoritas

Otoritas : Jurnal Ilmu Pemerintahan, 9 (1), April 2019, 88

itarian Regimes and its Possible Consequences.

Smith, T. E. (1960) Elections in Developing Countries. London: Macmillan

Sorenson, G. (1993). Democracy and Democratisation: Process and Prospects in a Changing the World. Boulder: Westview.

Suhuyini, S. I. (2018, July 14). The monetisation of politics, a threat to Ghana's democracy. Accra. Retrieved from https:// www.ghanaweb.com/ GhanaHomePage/NewsArchive/ The-monetisation-of-politics-a-
threat-to-Ghana-s-democracy668550

The World Governance Index. (2014). Retrieved from http:// www.worldbank.org

William, M. (1997). Money and Power in Uganda's 1996. Afr.j. polit. sci., 2, 168-179.

Willig, C. (2001) Introducing Qualitative Research in Psychology: Advances in theory and method. Buckingham, UK: Open University Press. 